\title{
Poprawa konkurencyjności działalności rolniczej w reformowanej Wspólnej Polityce Rolnej - wybrane zagadnienia prawne
}

1. Przedmiotem artykułu są zagadnienia związane $\mathrm{z}$ wdrażaniem reformy Wspólnej Polityki Rolnej (WPR), mającej na celu wzmocnienie dochodowości i poprawę konkurencyjności rolnictwa. Warunkiem rozwoju polityki gospodarczej państwa jest zdolność do efektywnego i długookresowego wzrostu. Aby można było realizować wyznaczone w jej ramach cele, konieczne jest instrumentarium prawno-ekonomiczne, które pozwoli nie tylko wyznaczać jej kierunek, ale także stymulować działania. W przypadku rolnictwa i jego konkurencyjności chodzi o właściwy dobór mechanizmów, które mogą zwiększać dochodowość sektora z uwzględnieniem przyjętych celów WPR. Przedmiotem analizy są więc zaproponowane na poziomie unijnym i krajowym instrumenty prawne, które mają służyć realizacji dziewięciu jej głównych celów wskazanych w art. 6 projektu rozporządzenia dotyczącego wsparcia ${ }^{1}$.

* Uniwersytet Przyrodniczy w Poznaniu.

${ }^{1}$ Wniosek dotyczący projektu rozporządzenia Parlamentu Europejskiego i Rady ustanawiającego przepisy dotyczące wsparcia na podstawie planów strategicznych sporządzanych przez państwa członkowskie w ramach wspólnej polityki rolnej (planów strategicznych WPR) i finansowanych z Europejskiego Funduszu Rolniczego Gwarancji (EFRG) i z Europejskiego Funduszu Rolnego na rzecz Rozwoju Obszarów Wiejskich (EFRROW) oraz uchylającego rozporządzenia Parlamentu Europejskiego i Rady (UE) nr 1305/2013 i rozporządzenia Parlamentu Europejskiego i Rady (UE) nr 1307/2013, COM(2018)392 (dalej: projekt rozporządzenia). 
Rolnictwo ma znacznie słabszą pozycję ekonomiczną niż inne działy gospodarki narodowej. Według ekonomistów jest ono niekonkurencyjne w porównaniu do sektorów nierolniczych pod względem społecznej wydajności pracy, technicznego wyposażenia oraz produktywności środków trwałych ${ }^{2}$. W efekcie niemal wszystkie kierowane do niego środki finansowe służą bezpośrednio podniesieniu jego dochodowości, a pośrednio - poprawie innych czynników oddziałujących na wzrost konkurencyjności³ ${ }^{3}$.

Pojęcie konkurencyjności jest szerokie i stanowi jeden z najbardziej niejednoznacznie zdefiniowanych terminów ekonomicznych ${ }^{4}$. Zgodnie z definicją przyjętą przez OECD jest to zdolność przedsiębiorstw, sektorów, regionów, krajów i obszarów ponadnarodowych do generowania relatywnie wysokich przychodów z wykorzystanych czynników produkcji (produktywności) i relatywnie wysokiego poziomu zatrudnienia w warunkach konkurencji międzynarodowej5. Konkurencyjność można także pojmować jako zdolność dowolnego układu gospodarczego do skutecznego funkcjonowania (trwania) i rozwoju w środowisku ciągłej rywalizacji ${ }^{6}$. Sprzyja ona tworzeniu warunków zapewniających wszystkim uczestnikom rynku, tj. podmiotom prowadzącym działalność gospodarczą, równy dostęp do ograniczonych zasobów oraz ich optymalne rozłożenie. Jako rezultat podejmowanych działań konkurencyjność jest weryfikowana przez sam rynek ${ }^{7}$.

Z kolei Komisja Europejska zdefiniowała konkurencyjność jako zdolność danego kraju do osiągania stabilnego wzrostu PKB per capita oraz zapewnienia obywatelom jak najwyższej stopy życiowej przy jak najniższym poziomie bezrobocia ${ }^{8}$. Oznacza zatem sposób wytwarzania towarów i usług, które spełniają wymogi rynków międzynarodowych, przy jednoczesnym utrzymaniu wysokiego i trwałego poziomu dochodów.

${ }^{2}$ B. Nosecka, K. Pawlak, Wybrane problemy konkurencyjności sektora rolno-spożywczego w Polsce i Unii Europejskiej, Warszawa 2014, s. 60.

${ }^{3}$ A. Niewiadomska, Konkurencyjność jako determinanta prawna europejskiej polityki rolnej, „Studia Iuridica” 2017, nr 72, s. 267-278.

${ }^{4}$ B. Nosecka, Czynniki ksztattujące konkurencyjność rolnictwa, w: A. Kowalski, M. Wigier (red.), Konkurencyjność polskiej gospodarki żywnościowej w warunkach globalizacji i integracji europejskiej, Warszawa 2014, s. 13.

5 OECD, Globalisation and Competitiveness: Relevant Indicators, „STI Working Papers” 1996, nr 16.

${ }^{6}$ J. Kulawik, B. Wieliczko, Wybrane finansowe aspekty konkurencyjności rolnictwa, „Zagadnienia Ekonomiki Rolnej” 2012, nr 4, s. 36-53.

7 J. Strojny, Pomiar konkurencyjności międzynarodowej rolnictwa Unii Europejskiej-ujęcie dynamiczne, w: W. Józwiak (red.), Wzmacnianie pozycji polskiego rolnictwa-propozycje wstępne, Warszawa 2012, s. 9 i n.

${ }^{8}$ European Commission, Sixth Periodic Report on the Social and Economic Situation and Development of the Regions of the European Union, Luxembourg 1999, s. 75. 
Według Mieczysława Adamowicza w przypadku agrobiznesu można ją rozumieć jako zbiór unikalnych umiejętności wynikających z posiadania i zarządzania swoistymi zasobami oraz ich wzajemnych relacji, trudnych do osiągnięcia i naśladowania przez konkurentów9. Z kolei Małgorzata Słodowa-Hełpa twierdzi, że konkurencyjność w rolnictwie opiera się zasadniczo na dwóch wzajemnie powiązanych elementach, którymi są efektywność i jakość. Obu towarzyszy właściwa organizacja rynku i samej produkcji. O konkurencyjności tej ostatniej, bez względu na jej wymiar (lokalny czy globalny), decyduje także koszt wytworzenia produktów ${ }^{10}$.

W literaturze z zakresu ekonomii wyróżnione zostały cztery grupy determinant konkurencyjności sektora rolno-spożywczego ${ }^{11}$. Podział ten został dokonany w oparciu o możliwość jej kontroli i bezpośredniego nań oddziaływania. Do pierwszej grupy determinant należą bodźce pozornie dające się kontrolować (ceny czynników produkcji ${ }^{12}$, uwarunkowania popytowe ${ }^{13}$ i międzynarodowa polityka ekonomiczna) oraz niekontrolowane (dostępność zasobów naturalnych, które mogą być wykorzystywane w procesie produkcji, a te są skończone). Do drugiej grupy można zaliczyć determinanty sterowane przez samego przedsiębiorcę (np. rolnika, przetwórcę), w tym jego strategię, właściwe zarządzanie, bezpieczeństwo, stosowaną technologię, przewagi kosztowe. Trzecią grupę stanowią projektowane przez państwo instrumenty konkurencyjności, najczęściej utożsamiane z jego oddziaływaniem na otoczenie biznesu. Chodzi tu o kreowanie polityki monetarnej i fiskalnej, badawczo-rozwojowej, polityki konkurencji, system edukacji czy doskonalenia zawodowego i polityki zatrudnienia. Do czwartej grupy determinant konkurencyjności sektora można zaliczyć normy prawne, określające np. zasady przyznawania wsparcia, organizację poszczególnych rodzajów produkcji, ustanawianie wymogów technicznych, sanitarnych, weterynaryjnych czy standardów jakości handlowej ${ }^{14}$.

${ }^{9}$ M. Adamowicz, Konkurencja i konkurencyjność w agrobiznesie. Aspekty teoretyczne i praktyczne, „Zagadnienia Ekonomiki Rolnej” 1999, nr 2-3, s. 11.

${ }^{10}$ M. Słodowa-Hełpa, Nowe oblicze konkurencyjności-konsekwencje dla polskiego sektora żywnościowego, „Ruch Prawniczy, Ekonomiczny i Socjologiczny” 2003, z. 2, s. 204-205.

${ }_{11}$ J. Reiljan, M. Hinrikus, A. Ivanov, Key Issues in Defining and Analysing the Competitiveness of a Country, „University of Tartu Economics and Business Administration Working Paper” 2000, nr 1, http://ssrn.com/abstract=418540 [dostęp: 11.10.2021].

${ }_{12} \mathrm{~W}$ handlu międzynarodowym ich wysokość można kształtować jedynie w ramach zawieranych umów handlowych i przy wykorzystaniu instrumentów rynku terminowego.

${ }^{13} \mathrm{~W}$ ograniczonym zakresie można na nie oddziaływać przy użyciu narzędzi marketingowych.

${ }_{14}$ B. Nosecka, W. Poczta, Czynniki decydujące o konkurencyjności sektora rolno-spożywczego, w: B. Nosecka, K. Pawlak, W. Poczta (red.), Wybrane aspekty konkurencyjności rolnictwa, Warszawa 2011, s. 24-25. 
Poprawa konkurencyjności sektora rolniczego od lat jest jednym z priorytetów WPR, obok rozwoju obszarów wiejskich. Jak zakłada prawodawca, Europa potrzebuje konkurencyjnego rolnictwa, które będzie innowacyjne, stabilne i zrównoważone. Jest to ważne dla zapewnienia bezpiecznej produkcji oraz wysokiej jakości, bogatej w składniki odżywcze, zróżnicowanej i przystępnej cenowo żywności, dzięki solidnej strukturze społeczno-gospodarczej na obszarach wiejskich. „Unowocześniona” Wspólna Polityka Rolna powinna zatem zwiększać europejską wartość dodaną, uwzględniając działania podejmowane na rzecz ochrony środowiska i przeciwdziałanie zmianie klimatu oraz spełniając oczekiwania obywateli w kwestii ich zdrowia, środowiska i klimatu ${ }^{15}$.

Celem artykułu jest ocena zaproponowanych na poziomie unijnym prawnych instrumentów oddziaływania na konkurencyjność rolnictwa. Pozwoli ona na udzielenie odpowiedzi, czy przyjęte rozwiązania normatywne mogą służyć poprawie dochodowości rodzimych producentów rolnych.

2. Konkurencyjność, pojmowana jako zdolność konkurowania, odnosi się do podejmowania działań dla osiągnięcia określonych celów, np. uzyskania dochodu, przez wiele podmiotów jednocześnie i często w podobnym zakresie. Można ją też traktować jako efekt konkurencji, co wskazuje, w jaki sposób przedsiębiorstwa rywalizują między sobą na rynku o zainteresowanie konsumentów ${ }^{16}$. Odbywa się ona w określonym otoczeniu gospodarczym i jest jednym z podstawowych elementów gospodarki rynkowej. Mimo że konkurencyjność cechuje ograniczona rola państwa, to w uzasadnionych, wyjątkowych sytuacjach dopuszcza jego ingerencję, co jest szczególnie widoczne w rolnictwie.

Przyjęta w UE polityka rolna jest bez wątpienia jedną z form interwencji państwa w mechanizm rynkowy. Stanowi system oddziaływania na gospodarkę rolną, który ma łagodzić sprzeczności pomiędzy celami mikro-

15 Wniosek dotyczący projektu rozporządzenia Parlamentu Europejskiego i Rady zmieniającego rozporządzenia (UE) nr 1308/2013 ustanawiającego wspólną organizację rynków produktów rolnych, (UE) nr 1151/2012 w sprawie systemów jakości produktów rolnych i środków spożywczych, (UE) nr 251/2014 w sprawie definicji, opisu, prezentacji, etykietowania i ochrony oznaczeń geograficznych aromatyzowanych produktów sektora wina, (UE) nr 228/2013 ustanawiającego szczególne środki w dziedzinie rolnictwa na rzecz regionów najbardziej oddalonych w Unii Europejskiej i (UE) nr 229/2013 ustanawiającego szczególne środki dotyczące rolnictwa dla mniejszych wysp Morza Egejskiego, COM(2018)394.

${ }^{16} \mathrm{~K}$. Beyer, Kapitat intelektualny jako podstawa przewagi konkurencyjnej przedsiębiorstw, „Zeszyty Naukowe Uniwersytetu Szczecińskiego. Studia i Prace Wydziału Nauk Ekonomicznych i Zarządzania” 2012, nr 25, ss. 241-254. 
i makroekonomicznymi. Wpływa na jej podstawowe parametry: cenę, zysk i dochód, stosując narzędzia ekonomiczne, prawne i administracyjne ${ }^{17}$. Jak zauważa Andrzej Czyżewski, może też prowadzić do zmiany podstawowych wielkości makroekonomicznych, w tym tempa rozwoju rolnictwa oraz relacji z innymi sektorami gospodarki ${ }^{18}$. Formą tej swoistej interwencji jest konkurencyjność, co zostało wskazane w art. 39 TFUE. Zgodnie $\mathrm{z}$ jego treścią celem WPR jest m.in. wzrost ekonomiczny osiągany poprzez optymalne wykorzystanie czynników produkcji, zwłaszcza siły roboczej.

Podstawową cechą gospodarki rynkowej jest konkurencja, a podmioty w niej funkcjonujące muszą odznaczać się konkurencyjnością, czyli elastycznością i zdolnością adaptacji do zmieniających się warunków działania, oraz podejmować takie decyzje, które zapewnią im uzyskanie przewagi konkurencyjnej ${ }^{19}$.

Jak zauważa Paweł Popardowski, kwestie ochrony konkurencji w rolnictwie są wypadkową dwóch polityk: konkurencyjności oraz polityki rolnej. Współistnienie ich reguł oraz tworzenie odpowiednich instrumentów prawnych zapewnia zarówno indywidualne, jak i zbiorowe korzyści z działalności sektora rolnego ${ }^{20}$. Ze względu na jego specyfikę mają do niego zastosowanie szczególne reguły wskazane w Traktacie o funkcjonowaniu Unii Europejskiej (TFUE). Przede wszystkim chodzi o art. 42 TFUE, który przewiduje szczególny rygor ochrony konkurencji, konieczny do osiągnięcia celów Wspólnej Polityki Rolnej określonych w art. 39 TFUE. Do formułowania tego rygoru upoważniony jest Parlament Europejski i Rada, natomiast nie rozstrzyga on o zakresie i sposobie ochrony ${ }^{21}$. Kwestie konkurencyjności w rolnictwie należą do rozwiązań normatywnych dotyczących ochrony konkurencji przed zakłóceniem jej na rynku unijnym. Zostały one zawarte w art. 101-109 TFUE odnoszących się do przedsiębiorców i pomocy publicznej.

Instrumenty prawne kształtujące czy oddziałujące na konkurencyjność rolnictwa zostały określone bezpośrednio w aktach normatywnych służących

${ }^{17}$ R. Sobiecki, Interwencjonizm w rolnictwie: dlaczego jest konieczny?, „Kwartalnik Nauk o Przedsiębiorstwie" 2015, nr 2, s. 38 i n.

18 A. Czyżewski, Interwencjonizm w polityce krajów wysokorozwiniętych, w: A. Czyżewski (red.), Makroekonomiczne problemy agrobiznesu w Polsce $w$ okresie przedakcesyjnym, Poznań 2003, s. 109-129.

19 Szerzej: M. Grzebyk, Z. Kryński, Konkurencja i konkurencyjność przedsiębiorstw: ujęcie teoretyczne, „Nierówności Społeczne a Wzrost Gospodarczy” 2011, nr 20, s. 107-117.

${ }^{20}$ P. Popardowski, Reguty konkurencji w rolnictwie w prawodawstwie Unii Europejskiej, Warszawa 2019, s. 135 i n.

${ }^{21}$ Ibidem. 
realizacji przyjętych celów WPR, a wraz z przeprowadzaną reformą ulegały one modyfikacjom ${ }^{22}$.

3. W czerwcu 2018 r. Komisja Europejska opublikowała propozycje legislacyjne związane z modernizacją i uproszczeniem Wspólnej Polityki Rolnej na lata 2021-2027. Warto przypomnieć, że na przestrzeni lat była ona wielokrotnie reformowana, a u jej podstaw od początku leżała poprawa konkurencyjności sektora rolnego oraz obszarów wiejskich ${ }^{23}$.

Nowy model WPR uwzględnia założenia strategii Europejski Zielony Ład, która opiera się na dążeniu do przekształcenia UE w sprawiedliwe i prosperujące społeczeństwo żyjące w nowoczesnej, zasobooszczędnej i konkurencyjnej gospodarce, która w 2050 r. osiągnie zerowy poziom emisji gazów cieplarnianych netto i w której wzrost gospodarczy będzie niezależny od wykorzystania zasobów naturalnych ${ }^{24}$.

Założenia reformy zostały przedstawione w postaci dziewięciu celów, wśród których wymienia się zwiększenie konkurencyjności i wydajności rolnictwa w sposób zrównoważony, tak by sprostać wyzwaniom związanym z wyższym popytem w warunkach ograniczonych zasobów i niepewnej sytuacji klimatycznej (art. 6 ust. 1 pkt b) projektu rozporządzenia). Rozwiązania legislacyjne $\mathrm{w}$ tym zakresie zostały ujęte $\mathrm{w}$ ramach kilku grup oddziaływania.

Po pierwsze, obejmują wsparcie dochodów poprzez płatności bezpośrednie (art. 29 projektu rozporządzenia), które przysługują osobom faktycznie prowadzącym działalność rolniczą i są związane z wielkością produkcji.

Po drugie, państwa członkowskie mogą ustanowić uzupełniające wsparcie dochodu dla młodych rolników podejmujących działalność gospodarczą w sektorze rolnym. Ma to być zachęta do inwestowania, gdyż prawodawca postrzega ich jako swego rodzaju „koło napędowe” konkurencyjności.

Po trzecie, państwa członkowskie mogą podejmować interwencje dotyczące niektórych sektorów i rodzajów produkcji lub konkretnych typów rolniczych. Pomoc w tym zakresie przysługuje, kiedy podmioty w nie zaangażowane znajdują się w trudnej sytuacji lub borykają się z trudnościami,

${ }^{22}$ Szerzej: A. Niewiadomska, Instrumenty prawne Wspólnej Polityki Rolnej wplywajace na konkurencyjność polskiego rolnictwa, Warszawa 2019, s. 50 i n.

${ }^{23}$ S. Kowalski, Realizacja Wspólnej Polityki Rolnej Unii Europejskiej i jej konsekwencje dla europejskiego rolnictwa, „Nauki Ekonomiczne” 2017, t. 25, s. 91-112.

${ }^{24}$ Komisja Europejska, Komunikat Komisji do Parlamentu Europejskiego, Rady Europejskiej, Rady, Komitetu Ekonomiczno-Społecznego i Komitetu Regionów. Europejski Zielony Ead, Bruksela, 11.12.2019, $\operatorname{COM(2019)~} 640$ final. 
a prawodawca dostrzega konieczność zwiększenia ich konkurencyjności albo zrównoważonego charakteru lub poprawy jakości. Zgodnie z art. 30 projektu rozporządzenia wsparcie dochodów związane z wielkością produkcji można przyznać jedynie wtedy, gdy poszczególne sektory bądź rodzaje produkcji są istotne ze względów gospodarczych, społecznych lub środowiskowych. Prawodawca wymienia tu: zboża, nasiona oleiste, rośliny wysokobiałkowe, rośliny strączkowe, len, konopie, ryż, orzechy, ziemniak skrobiowy, mleko i przetwory mleczne, nasiona, mięso baranie i mięso kozie, wołowinę i cielęcinę, oliwę z oliwek, jedwabniki, susz paszowy, chmiel, burak cukrowy, trzcinę cukrową i cykorię, owoce i warzywa, zagajniki o krótkiej rotacji oraz inne uprawy niespożywcze, z wyłączeniem drzew, stosowane do wytwarzania produktów, które mogą zastępować materiały kopalne.

Przykładowo w sektorze owoców i warzyw jako jeden z głównych celów poprawy jego kondycji wskazano konieczność prowadzenia badań i rozwoju w zakresie zrównoważonych metod produkcji (np. uwzględniających odporność na agrofagi), potrzebę wdrażania innowacyjnych praktyk zwiększających konkurencyjność gospodarczą i wspierających rozwój rynków (art. 42 lit. c) projektu rozporządzenia). Z kolei w sektorze wina rekomendowane są działania polegające na wsparciu funkcjonowania zrównoważonych systemów produkcji i zmniejszenia jego wpływu na środowisko. Jego właściwy rozwój ma prowadzić do poprawy wyników przedsiębiorstw winiarskich oraz lepszego dostosowania ich do popytu na rynku (art. 51 lit. a), b) i c) projektu rozporządzenia). Mowa tu zwłaszcza o wzroście zbywalności i rozwoju innowacyjnych produktów, procesów i technologii oraz podnoszeniu wartości na każdym etapie łańcucha dostaw. Podobne rozwiązania przyjęto w pozostałych „wrażliwych” sektorach, tj. chmielu (art. 55 projektu rozporządzenia) oraz oliwy z oliwek i oliwek stołowych (art. 55-58 projektu rozporządzenia).

Reforma WPR i realizacja wymienionych wyżej celów polega na wytyczeniu i przyjęciu na poziomie państw członkowskich planów strategicznych, które muszą być zatwierdzone przez Komisję Europejską. W omawianym zakresie mają one obejmować kompleksowy harmonogram wsparcia, służący stosowaniu instrumentów obu filarów WPR, tj. płatności bezpośrednich, programów sektorowych (przeniesionych ze wspólnej organizacji rynków) oraz instrumentów rozwoju obszarów wiejskich. Przy czym cele dotyczące poprawy konkurencyjności mogą, ale nie muszą być realizowane, ponieważ dobór poszczególnych instrumentów został pozostawiony państwom członkowskim i to one są zobligowane do wyboru co najmniej jednego z nich (art. 43, 48, 51, 55 i 56 projektu rozporządzenia). 
Prawodawca wymaga, aby plany uwzględniały również założenia Europejskiego Zielonego Ładu, co oprócz zrównoważenia metod produkcji w unijnym sektorze rolnym UE i transformacji europejskich systemów żywnościowych ma na celu także wdrożenie instrumentów wspierających rolnictwo w zakresie dochodów i konkurencyjności, pozycji rolników w łańcuchu dostaw żywności, miejsc pracy na obszarach wiejskich i wzrostu gospodarczego ${ }^{25}$.

4. W ramach przyjętych zobowiązań Ministerstwo Rolnictwa i Rozwoju Wsi przygotowało i poddało konsultacjom społecznym projekt Planu Strategicznego dla Wspólnej Polityki Rolnej na lata 2023-202726. Zawarte w nim propozycje zostały oparte na analizie SWOT rodzimego rolnictwa i rozwoju obszarów wiejskich dla każdego z dziewięciu celów szczegółowych WPR (art. 103 projektu rozporządzenia). Pozwoliło to na określenie ich mocnych i słabych stron oraz szans i zagrożeń, w tym głównych potrzeb. Przyjęto, że plan ma nie tylko wspierać zrównoważony rozwój polskiego rolnictwa, ale także przyczyniać się do poprawy dochodów rolniczych, co w konsekwencji zwiększy konkurencyjność gospodarstw rolnych.

Przeprowadzona analiza mocnych stron wskazuje na duże znaczenie sektora rolno-spożywczego w gospodarce narodowej, a jednocześnie ujawnia pewne przewagi konkurencyjne w handlu międzynarodowym. Polska posiada znaczne zasoby czynników wytwórczych w rolnictwie oraz względnie konkurencyjne struktury rynkowe w ogniwach łańcucha marketingowego żywności. $Z$ analizy wynikają również dalsze szanse rozwoju sektora - widać znaczny potencjał ekonomiczny rozwoju działań kooperacyjnych, a także progres w wytwarzaniu żywności wysokiej jakości. Jednakże sektor nie jest pozbawiony słabych stron. Należą do nich: duża liczba gospodarstw rolnych, ich rozdrobniona struktura oraz niska skłonność do poziomej i pionowej integracji, co ma negatywny wpływ na siłę przetargową rolnictwa w łańcuchu dostaw; duży udział słabych jakościowo i ilościowo kompleksów glebowych; dość niska efektywność wykorzystania czynników wytwórczych w rolnictwie; niska innowacyjność i zaawansowanie technologiczne w produkcji rolnej, w tym niski poziom technologii prośrodowiskowych. Niosą one ze sobą pewne zagrożenia. Przede wszystkim pojawiające się z coraz większą intensywnością nega-

${ }^{25}$ Commission Staff Working Document, Analysis of links between CAP Reform and Green Deal, Brussels, 20.5.2020, SWD(2020) 93 final.

${ }^{26}$ Szerzej: Konsultacje drugiej wersji projektu Planu Strategicznego dla Wspólnej Polityki Rolnej na lata 2023-2027, https:/www.gov.pl/web/wprpo2020/konsultacje-drugiej-wersji-projektu-planu-strategicznego-dla-wspolnej-polityki-rolnej-na-lata-2023-2027 [dostęp: 30.09.2021]. 
tywne zmiany klimatyczne powodują wzrost ryzyka produkcyjnego. Niepewność produkcji i jej dochodowości przyczynia się do odpływu młodych mieszkańców z terenów wiejskich. Jednocześnie wzrost koncentracji i siły przetargowej, przy niewielkiej integracji producentów rolnych w ogniwach marketingowych łańcuchów żywnościowych, ogranicza ich konkurencyjność. Towarzyszą temu zmiany preferencji konsumentów, prowadzące do powstania trendów skutkujących spadkiem popytu na produkty rolno-żywnościowe pochodzenia krajowego. Za poważne zagrożenie uważa się także wykluczenie cyfrowe części producentów rolnych, co uniemożliwia im udział w wielu działaniach o charakterze gospodarczym, decydujących o ich pozycji na rynku. Z kolei w międzynarodowym handlu rolno-żywnościowym coraz częściej dostrzega się narastający protekcjonizm, co pobudza konkurencję ze strony krajów rozwijających ${ }^{27}$.

Na podstawie przedstawionych wyników analizy SWOT można stwierdzić, że aby wzmocnić konkurencyjność rodzimego rolnictwa, konieczne jest podjęcie działań o charakterze wspierającym, a jednocześnie interwencyjnym. Opierając się na założeniach reformy WPR i zaleceniach Komisji, zostały zaproponowane interwencje m.in. w zakresie płatności bezpośrednich i obszarowych z II filaru WPR, instrumenty służące zapobieganiu niszczeniu potencjału produkcyjnego gospodarstw, wspieraniu restrukturyzacji i modernizacji małych gospodarstw, rozwojowi różnych form współpracy rolników i producentów rolnych, poprawie łańcuchów dostaw i optymalizacji produkcji, a także poprawie struktury agrarnej i ograniczeniu czasochłonności pracy $\mathrm{w}$ gospodarstwie ${ }^{28}$. Wskazane interwencje, polegające na wsparciu finansowym, dokonywane są z wykorzystaniem mechanizmów prawnych związanych z funkcjonowaniem europejskich funduszy rolnych.

Dokonując analizy zaproponowanych w Planie form wsparcia konkurencyjności, warto zauważyć, że niektóre z interwencji odnoszą się do niej bezpośrednio, a pozostałe są dodatkowym bądź ubocznym efektem innych działań ${ }^{29}$. Ustalenie ich nastąpiło w oparciu o wskaźniki rezultatu w odnie-

27 Załącznik nr 4: Analiza SWOT. Cel 2: Zwiększenie zorientowania na rynek i poprawa konkurencyjności, w tym większe ukierunkowanie na badania naukowe, technologię i cyfryzację, https://www.gov.pl/web/wprpo2020/konsultacje-drugiej-wersji-projektu-planu-strategicznego-dla-wspolnej-polityki-rolnej-na-lata-2023-2027 [dostęp: 17.09.2021].

${ }^{28}$ Dokument roboczy służb Komisji: Zalecenie Komisji dla Polski w sprawie planu strategicznego WPR, towarzyszący dokumentowi: Komunikat Komisji do Parlamentu Europejskiego, Rady, Europejskiego Komitetu Ekonomiczno-Społecznego i Komitetu Regionów, Zalecenia dla państw członkowskich w sprawie ich planów strategicznych dotyczących wspólnej polityki rolnej, Bruksela, 18.12.2020, SWD(2020) 389 final.

${ }^{29}$ Plan Strategiczny dla Wspólnej Polityki Rolnej na lata 2023-2027, wersja II, Warszawa 2021. 
sieniu do wsparcia dochodu, pozwalające ocenić bezpośrednie i natychmiastowe skutki interwencji (np. odsetek dochodów rolników pochodzący ze wsparcia dochodu) ${ }^{30}$.

W ramach pierwszej grupy, tj. interwencji bezpośrednich, należy wymienić inwestycje w gospodarstwach rolnych zwiększające konkurencyjność, które mogą przybierać postać dotacji lub instrumentów finansowych ${ }^{31}$. Obie formy są finansowane z Europejskiego Funduszu Rolnego na rzecz Rozwoju Obszarów Wiejskich, a swym zasięgiem obejmują cały kraj. Dotacje stanowią formę refundacji części kosztów kwalifikowalnych działań mających na celu: racjonalizację technologii produkcji, wprowadzenie nowoczesnych, w tym cyfrowych, technologii lub innowacji, zmianę profilu produkcji, poprawę jakości produkcji, zwiększenie wartości dodanej produktu. Mogą one dotyczyć produkcji i przygotowania do sprzedaży produktów rolnych wytwarzanych w gospodarstwie, przy czym możliwa będzie realizacja dwóch rodzajów operacji: 1) dotyczącej produkcji zwierzęcej, a polegającej na budowie lub modernizacji budynków bądź 2) budowli służących do produkcji zwierzęcej z wykorzystaniem nowoczesnych technologii, w tym w miarę możliwości ograniczających szkodliwy wpływ rolnictwa na środowisko, energooszczędnych, niskoemisyjnych oraz produkcji ekologicznej. Wspierane będą inwestycje materialne lub niematerialne, mające bezpośredni związek z działalnością rolniczą prowadzoną w gospodarstwie, w tym dotyczące przechowywania, suszenia, magazynowania oraz przygotowywania produktów rolnych do sprzedaży, a także zapewnienia pasz dla zwierząt utrzymywanych w gospodarstwie. Jednocześnie mogą być realizowane wyłącznie takie działania w ramach interwencji, które będą przyczyniały się do poprawy konkurencyjności gospodarstwa rolnego i jego zorientowania na rynek w wyniku restrukturyzacji.

Wskazane powyżej instrumenty finansowe mają ułatwić dostęp do kapitału na rzecz inwestycji na odtworzenie majątku wytwórczego w rolnictwie. W jej ramach mogą być prowadzone wyłącznie działania dotyczące produkcji produktów rolnych, żywnościowych, jak i nieżywnościowych, przygotowania do sprzedaży produktów rolnych wytwarzanych w gospodarstwie oraz sprzedaży bezpośredniej. Instrumenty te zapewniają wsparcie jedynie w przypadku nowych inwestycji, co do których oczekuje się, że będą finansowo opłacalne, tj. generujące dochody lub oszczędności. Do wsparcia w zakresie podstawowej produkcji rolnej kwalifikują się inwestycje mate-

${ }^{30}$ Filar I - fiszki wskaźników rezultatu, rozporządzenie wykonawcze Komisji (UE) nr 834/2014 z 22 lipca 2014 r. ustanawiające zasady stosowania wspólnych ram monitorowania i ewaluacji Wspólnej Polityki Rolnej (Dz. Urz. UE L 230, 1.08.2014, s. 1-7).

${ }^{31}$ Plan Strategiczny..., s. 222-227. 
rialne i niematerialne oraz kapitał obrotowy zgodnie z art. 74. ust. 3 projektu rozporządzenia o planach. Jak wskazano wyżej, celem interwencji jest zwiększenie konkurencyjności gospodarstw, co może być zrealizowane poprzez: a) racjonalizację technologii produkcji; b) wprowadzenie nowoczesnych, w tym cyfrowych, technologii lub innowacji; c) zmianę profilu produkcji; d) poprawę jakości produkcji. W ramach interwencji możliwa będzie realizacja inwestycji: a) o charakterze innowacyjnym lub wpływającym na cyfryzację, automatyzację działalności rolniczej prowadzonej w gospodarstwie, w tym rolnictwo precyzyjne; b) innych niż objęte zakresem w punkcie a), ale dotyczących produkcji rolnej w zakresie racjonalizacji technologii produkcji, zmiany profilu produkcji, poprawy jakości produkcji; c) polegających na rozwoju produkcji roślinnej lub zwierzęcej w gospodarstwie (głównie w przypadku gospodarstw poniżej 25 tys. euro wartości ekonomicznej i młodego rolnika); d) dotyczących przechowalnictwa, suszenia, magazynowania, przygotowywania produktów rolnych do sprzedaży; e) dotyczących sprzedaży bezpośredniej. Instrumenty te przyjmują postać gwarancji wraz dotacjami na spłatę odsetek od zaciągniętych kredytów.

Poprawa konkurencyjności jest również realizowana w ramach wsparcia dochodów związanych z produkcją roślinną i zwierzęcą ${ }^{32}$. Przyjmuje ona formę płatności rocznej do kwalifikującej się powierzchni do uprawy buraków cukrowych, chmielu, lnu, konopi włóknistych, pomidorów, truskawek, ziemniaków skrobiowych, roślin pastewnych oraz roślin strączkowych na ziarno. W produkcji zwierzęcej obejmuje ona wsparcie dochodów związane $\mathrm{z}$ chowem bydła, owiec i kóz. Jest oferowana w formie płatności rocznej do sztuki zwierzęcia.

Wsparcie zostało także przewidziane w ramach interwencji sektorowych. Mowa tu o sektorze pszczelarskim, gdzie przyjęło postać pomocy technicznej oraz refundacji kosztów podnoszenia poziomu wiedzy pszczelarskiej czy modernizacji gospodarstw pasiecznych ${ }^{33}$, jak również o sektorze owoców i warzyw, gdzie celem wsparcia jest włączenie organizacji producentów owoców i warzyw do realizacji innowacyjnych operacji, tj. takich, które promują zrównoważone metody produkcji, odpowiadają na zapotrzebowanie rynkowe, zmierzają do optymalizacji produkcji, a tym samym wpływają na poprawę jego konkurencyjności ${ }^{34}$. Pomoc ma formę refundacji części kosztów kwalifikowanych inwestycji.

Zwiększeniu konkurencyjności, zarówno w perspektywie krótko-, jak i długoterminowej, ma służyć też wsparcie rozwoju małych gospodarstw,

\footnotetext{
${ }^{32}$ Ibidem, s. 222-227.

${ }^{33}$ Ibidem, s. 167-180.

${ }^{34}$ Ibidem, s. 194 i n.
} 
tj. o wielkości ekonomicznej poniżej 25 tys. euro. Jego celem jest wzrost wartości sprzedaży wyprodukowanych lub przetworzonych produktów rolnych, czyli wzmocnienie orientacji rynkowej ${ }^{35}$. Ponadto konieczna jest poprawa funkcjonowania łańcuchów wartości w gospodarstwie i poza nim poprzez rozwój współpracy. Wsparcie jest ukierunkowane na realizację działań inwestycyjnych, które mają wzmocnić pozycję rynkową rolników, a także wpłynąć na dywersyfikację i skracanie etapów łańcucha żywnościowego. Pomoc udzielana jest m.in. na inwestycje materialne i niematerialne dotyczące przetwarzania lub sprzedaży produktów rolnych ${ }^{36}$.

5. Reforma WPR przewiduje szereg instrumentów oddziałujących na rozwój konkurencyjności w rolnictwie i tym samym poprawiających jej dochodowość. Zastosowanie ich wynika zarówno z wytyczonych kierunków reformy, w teorii adekwatnych do potrzeb sektora, jak i ze zobowiązań międzynarodowych i przyjętej strategii Zielony Lad. Stanowią one zachętę dla producentów rolnych do modyfikacji stosowanych metod produkcji czy działań w obszarze okołorolniczym. Instrumenty te nie są nowatorskie, w większości były już oferowane. Podstawą ich opracowania była przeprowadzona w każdym państwie członkowskim analiza SWOT, a do jej oczekiwanej efektywności zostały dodatkowo zastosowane wskaźniki ekonomiczne. Niemniej poprawa konkurencyjności zależy nie tylko od propozycji wsparcia ze strony państwa, ale także od postaw producentów rolnych. To oni, jako adresaci pomocy, powinni podejmować określone działania i przyjmować pewne postawy w celu wzmocnienia swojej pozycji na rynku rolnym. Ich ocena i odpowiedź na pytanie, czy przyjęte rozwiązania normatywne przyczyniają się do poprawy dochodowości rodzimych producentów rolnych, będzie możliwa zatem dopiero w toku realizacji WPR.

Rodzime rolnictwo i przemysł rolno-spożywczy nadal podlegają procesowi przemian restrukturyzacyjnych i modernizacyjnych na wszystkich etapach łańcucha dostaw ${ }^{37}$. Znajduje to wyraz w wachlarzu oferowanych instrumentów wsparcia. Zasadniczym ich celem powinna być poprawa efektywności wykorzystania i produktywności czynników wytwórczych, czemu powinien towarzyszyć wzrost innowacyjności i zastosowania nowoczesnych technologii. Dodatkowo - z punktu widzenia producenta rolnego - powinna

35 Ibidem, s. 235-238.

36 Ibidem, s. 239-248.

37 Szerzej: M. Wigier, A. Wasilewski, W. Łopaciuk, Ocena wplywu wybranych instrumentów polityki publicznej majacych wptyw na zmiany strukturalne w rolnictwie i na obszarach wiejskich, w: A. Kowalski, M. Wigier (red.), Konkurencyjność polskiej gospodarki..., s. 37 i n. 
je cechować trwałość stosowania i pewna przewidywalność. Z tego względu konieczne jest ułatwienie dostępu do kapitału szczególnie na rzecz inwestycji poprawiających konkurencyjność w rolnictwie, zaś oferowane instrumenty powinny być całościowe i komplementarne względem siebie, by oprócz poprawy konkurencyjności mogły pozytywnie wpływać na rozwój obszarów wiejskich.

Bez wątpienia należy zgodzić się z poglądem Romana Sobieckiego, że rolnika powinna obecnie cechować wielofunkcyjność, polegająca na wytwarzaniu zarówno dóbr i usług rynkowych, jak i dóbr o charakterze publicznym (np. stanowiących efekt troski o środowisko naturalne). Pobudzanie konkurencyjności poprzez stosowanie narzędzi interwencjonizmu nie ma powodować ograniczenia skali produkcji rolnej, lecz dzięki wzrostowi dochodów realnych ma prowadzić do wzrostu popytu ${ }^{38}$.

\section{BIBLIOGRAFIA}

Adamowicz M. (1999), Konkurencja i konkurencyjność w agrobiznesie. Aspekty teoretyczne i praktyczne, „Zagadnienia Ekonomiki Rolnej” nr 2-3.

Beyer K. (2012), Kapitat intelektualny jako podstawa przewagi konkurencyjnej przedsiębiorstw, „Zeszyty Naukowe Uniwersytetu Szczecińskiego. Studia i Prace Wydziału Nauk Ekonomicznych i Zarządzania” nr 25.

Czyżewski A. (2003), Interwencjonizm w polityce krajów wysokorozwiniętych, w: A. Czyżewski (red.) Makroekonomiczne problemy agrobiznesu $w$ Polsce $w$ okresie przedakcesyjnym, Poznań.

European Commission (1999), Sixth Periodic Report on the Social and Economic Situation and Development of the Regions of the European Union, Luxembourg.

Grzebyk M., Kryński Z. (2011), Konkurencja i konkurencyjność przedsiębiorstw: ujęcie teoretyczne, „Nierówności Społeczne a Wzrost Gospodarczy” nr 20.

Kowalski S. (2017), Realizacja Wspólnej Polityki Rolnej Unii Europejskiej i jej konsekwencje dla europejskiego rolnictwa, „Nauki Ekonomiczne” t. 25.

Kulawik J., Wieliczko B. (2012), Wybrane finansowe aspekty konkurencyjności rolnictwa, „Zagadnienia Ekonomiki Rolnej” nr 4.

Niewiadomska A. (2017), Konkurencyjność jako determinanta prawna europejskiej polityki rolnej, ,Studia Iuridica” nr 72.

Niewiadomska A. (2019), Instrumenty prawne Wspólnej Polityki Rolnej wpływajace na konkurencyjność polskiego rolnictwa, Warszawa.

Nosecka B. (2014), Czynniki ksztattujące konkurencyjność rolnictwa, w: A. Kowalski, M. Wigier (red.), Konkurencyjność polskiej gospodarki żywnościowej w warunkach globalizacji i integracji europejskiej, Warszawa.

Nosecka B., Pawlak K. (2014), Wybrane problemy konkurencyjności sektora rolno-spożywczego w Polsce i Unii Europejskiej, Warszawa.

${ }^{38}$ R. Sobiecki, Interwencjonizm ..., s. 47. 
Nosecka B., Poczta W. (2011), Czynniki decydujące o konkurencyjności sektora rolno-spożywczego, w: B. Nosecka, K. Pawlak, W. Poczta, Wybrane aspekty konkurencyjności rolnictwa, Warszawa.

OECD (1996), Globalisation and Competitiveness: Relevant Indicators, „STI Working Papers" nr 16.

Popardowski P. (2019), Reguly konkurencji w rolnictwie w prawodawstwie Unii Europejskiej, Warszawa.

Reiljan J., Hinrikus M., Ivanov A. (2000), Key Issues in Defining and Analysing the Competitiveness of a Country, „University of Tartu Economics and Business Administration Working Paper" nr 1, http://ssrn.com/abstract=418540.

Słodowa-Hełpa M. (2003), Nowe oblicze konkurencyjności - konsekwencje dla polskiego sektora żywnościowego, „Ruch Prawniczy, Ekonomiczny i Socjologiczny” z. 2.

Sobiecki R. (2015), Interwencjonizm w rolnictwie: dlaczego jest konieczny?, „Kwartalnik Nauk o Przedsiębiorstwie" nr 2.

Strojny J. (2012), Pomiar konkurencyjności międzynarodowej rolnictwa Unii Europejskiej - ujęcie dynamiczne, w: W. Józwiak (red.), Wzmacnianie pozycji polskiego rolnictwapropozycje wstepne, Warszawa.

Wigier M., Wasilewski A., Łopaciuk W. (2014), Ocena wplywu wybranych instrumentów polityki publicznej majacych wptyw na zmiany strukturalne $w$ rolnictwie i na obszarach wiejskich, w: A. Kowalski, M. Wigier (red.), Konkurencyjność polskiej gospodarki żywnościowej w warunkach globalizacji i integracji europejskiej, Warszawa.

\section{IMPROVING THE COMPETITIVENESS OF AGRICULTURAL ACTIVITY IN THE REFORMED COMMON AGRICULTURAL POLICY: SELECTED LEGAL ISSUES}

\section{Summary}

The article covers issues related to the implementation of the Common Agricultural Policy reform aimed at strengthening profitability and improving competitiveness of agriculture. Its aim is to assess the legal instruments proposed at the EU level in this respect and to determine whether the adopted normative solutions can serve to improve the profitability of domestic agricultural producers. In conclusion it is stated that the reform provides for a number of instruments that influence the development of competitiveness in agriculture and thereby improve the profitability of the agricultural business. Their implementation results both from the directions of the reform formulated with a view of meeting the needs of the sector, as well as from international obligations and the adopted European Green Deal Strategy. However, although the incentives created prompt the agricultural producers to modify their production methods and ways or activities undertaken in the fields related to agriculture, the strengthening of their market position depends on their operation.

Keywords: competitiveness, profitability, Common Agricultural Policy, strategic plan 


\section{MIGLIORARE LA COMPETITIVITÀ DELL'ATTIVITÀ AGRICOLA NELLA POLITICA AGRICOLA COMUNE - ALCUNE QUESTIONI GIURIDICHE SCELTE}

\section{Riassunto}

La problematica discussa nell'articolo abbraccia questioni legate all'attuazione della riforma della politica agricola comune che va in una direzione di rafforzare la redditività e di migliorare la competitività dell'agricoltura. L'articolo si propone di valutare gli strumenti giuridici proposti a tal proposito a livello dell'UE, oltre che di rispondere alla domanda se le soluzioni normative adottate possano portare a migliorare la redditività dei produttori agricoli nazionali. Nella parte conclusiva è stato appurato che la riforma prevede una serie di strumenti che influiscano sullo sviluppo della competitività in agricoltura e quindi migliorino la sua redditività. La loro attuazione è dovuta sia alle implicazioni teoriche, adeguate alle esigenze del settore, sia agli obblighi internazionali e alla strategia di Green Deal europeo adottata. Sebbene, per i produttori agricoli, essi rappresentino un incentivo a modificare i metodi di produzione, o le attività connesse all'agricoltura, sono le attività da loro intraprese a rafforzare la loro posizione di mercato.

Parole chiave: competitività dell'attività agricola, politica agricola comune, redditività 